\title{
Development of a Test to Evaluate Students' Analytical Thinking Based on Fact versus Opinion Differentiation
}

\section{Taveep Thaneerananon}

PhD., Institute for innovative Learning, Mahidol University, Nakhon Pathom, Thailand, taveep_t@hotmail.com

\section{Wannapong Triampo}

Assoc. Prof., Department of Physics, Faculty of Science, Mahidol University, Bangkok, Thailand, wannapong.tri@mahidol.ac.th

\section{Artorn Nokkaew}

PhD., Institute for innovative Learning, Mahidol University, Nakhon Pathom, Thailand, artorn.nok@mahidol.edu

Nowadays, one of the biggest challenges of education in Thailand is the development and promotion of the students' thinking skills. The main purposes of this research were to develop an analytical thinking test for $6^{\text {th }}$ grade students and evaluate the students' analytical thinking. The sample was composed of $35676^{\text {th }}$ grade students in 2014 academic year at schools in Samuthsakorn province, the largest sample size that has been reached so far for an analytical thinking test in Thailand. The instruments for collecting data were the analytical thinking skill test; Fact vs. Opinion test (F vs. O test) and Ordinary National Educational based test (O-NET based test). The collected data were analysed through TAP 6.65, SIA1.0.1 and SPSS 22 statistical programs. The results revealed statistic consistency between $\mathrm{F}$ vs. $\mathrm{O}$ test and O-NET based test. In addition, most $6^{\text {th }}$ grade students were in "Unsatisfactory" level for analytical thinking skills. Though improvements are much needed, we believe that the developed Fact vs. Opinion test suits for the promotion and evaluation of the students' analytical thinking skills.

Key Words: analytical thinking skill, fact vs. opinion, O-NET based test, quality of test, ATS test

\section{INTRODUCTION}

Democracies and those countries on the verge of it may hold common values, such as freedom of thought and self-decision. These values require self-responsibility and truthful knowledge for each individual and education is a key to such a personal development. Individuals are presented with information in a variety of forms that hold different degrees of truth and having the ability to think critically may prevent us from falling victim to deception (Pimsai, 2002). Many educators are enthusiastic about and 
increasingly focusing on thinking skills, in particular recognizing the importance of higher-order thinking skills for individual development. Higher order mental processes are needed to solve problems and make decisions in everyday life including comparing, evaluating, justifying, and making inferences (Wheeler \& Haertel, 1993). Thus, the development of higher order thinking skills is necessary for students to develop a rational thinking, analytical thinking and synthetic thinking for problem-solving, decision making and seeking knowledge by themselves (Sinlarat, 2000). This will help them confront the rapidly changing world.

The examination of students' thinking ability could be a measure of educational quality and standards in schools. Superior educational quality would also lead to a national development and perhaps a better quality of life in society.

Critical thinking is thinking act based on knowledge, available evidence, exploration and information to arrive at a reasonable conclusion. Therefore, critical thinking is what instructors should prioritize and promote as a practice skill for students. Analytical thinking is about breaking things (situations, practices, problems, statements, ideas, theories, arguments) down into their component parts. Analytical / critical thinking is often associated with directed thinking, i.e. solving problems, seeking the truth and developing understanding, with the focus on a desired outcome (Stella, 2003). Analytical thinking is blended with critical thinking, especially as a part of the problem solving process, considered essential for providing the skills required to prepare children for a more complex life and work environment in $21^{\text {st }}$ century. Thus, it is important in the classroom to promote thinking ability comprising six dimensions; applicative, conceptual, analytical, synthesis, creative and critical thinking (Charoenwongsak, 2002, 2003; Chaijaroen Sumalee and others, 2006).

The main goal of Core Curriculum for Basic Education 2008, educational standard IV, is that the learner shall be capable of analytical, critical, synthetic, creative and visionary thinking in addition to mathematic and scientific thinking skills (Ministry of Education, 2008).Thailand's educational system should focus on intelligence cultivation, development of the students' creative and critical thinking and the development of emotional abilities (Ministry of Education, 2001).

However, there has been evidence in the past two decades that efforts to develop thinking skills of students have been done only in a limited manner and have not yet reached the desired goal (Ministry of Education, 2006). In reference to the National Education Act1999, academic achievement, thinking and searching skills at 6th and 9th grades ranked at the "Not Satisfactory" level (Wirachchai, N, Wongwanich, S. \& Roengrtrakoon, A., 2003). According to the research work of Navapornpaisarn (1991), the critical thinking test developed by Watson and Glazer faces problems of being different in culture and environment, when used with secondary school students in Thailand. However, Navapornpaisarn suggested that the language and cultural content of the test should be adapted appropriately for Thai students. 


\section{Research Problem}

The report of external audit of The Office for National Education Standards and Quality Assessment (ONESQA)(2007) showed that at the national level, the standard was evaluated as the lowest, or the most problematic standard was Standard IV (the students' ability in analytical, synthetic, creative and critical thinking, considering, and vision). According to the Standard Quality Assessment with regard to these abilities, most Thai students performed at "To be improved" level and only10.4\% performed at "Good" level. In addition, in more than $90 \%$ of schools, the students' average score in learning achievement, thinking skill and searching skill, was ranked in the category of "To be improved". The most problematic one was the ratings of the analytical thinking of the Thai children, sparking a serious urge for improvement (Ministry of Education, 2006). The finding of several studies for the development of analytical thinking indicated that teachers were aware of the significance of learning management for such purpose yet lacked knowledge and experience to promote and encourage analytical thinking (Kaewsudjarit, 1998: 95-97). This teachers' ineptitude has inevitably caused ineffective learning activities that fail to help develop analytical thinking in students (Art-in, 2012). Thinking skills and the application of knowledge for solving problems and decisionmaking are important parts in the learning process in schools with special concern to primary students who have focused on the development of cognitive skills in accordance with the core curriculum for basic education BE 2551(2008).

For the above mentioned reasons, the researchers believed that the development of the Analytical Thinking Skill test (ATS test) can be a useful tool for teachers to evaluate students' analytical thinking skills through making a distinguish between Fact and Opinion ( $\mathrm{F}$ vs. $\mathrm{O}$ test). In Thailand, the test needs to meet the standard of Basic Education Core Curriculum 2008 which sets the learning standard and proposes indicators for measurement of learning progress for $6^{\text {th }}$ grade students (Ministry of Education, 2008). Furthermore, thinking skills and knowledge application play an important part in the learning process in schools especially for decision making and thinking skills to solve problem-solving in various situations. Thus, the practice of analytical thinking skills is an important factor in the development of children's intelligence as to advance independent thinking and critical minds required to promote country development (Susaorat, 1998:9).

Based on concepts, theories and researches related to analytical thinking as mentioned beforehand, we have developed an ATS test for $6^{\text {th }}$ grade students in form of a Fact vs. Opinion test, primarily to evaluate their analytical thinking skills, but also to promote learning and practice of analytical thinking. We believed that this Fact vs. Opinion test has a potential to elevate the level of $6^{\text {th }}$ grade students' analytical thinking in schools under the Primary Education Office of Samuthsakorn Province.

\section{Research Objectives}

1. To develop the analytical thinking test for $6^{\text {th }}$ grade students.

2. To evaluate the students' analytical thinking skills by teaches after using the analytical thinking test. 


\section{METHOD \\ Participants}

The population was $42876^{\text {th }}$ grade students under the Primary Education Office of Samuthsakorn Province in the 2014 academic year. Samuthsakorn province was chosen as the study location as Memorandum of Understanding has been initiated between the Institute for Innovative Learning, Mahidol University and the governing body of the province allowing us to perform a relevant research there. The sample size consisted of $35676^{\text {th }}$ grade students, selected from 76 Schools during first semester of 2014.

\section{Research Design}

The test and its set-up were designed to reveal quantitative aspect of the students' learning progress in analytical thinking. The research procedure would indicate the need for further evaluation of students' analytical thinking skills and trigger an adequate thinking process and is meant to facilitate situation dependent problem-solving skills. To help students achieve these purposes, the researcher used item response theory to identify the quality of the test by determining item difficulty, discriminative power including the reliability and validity of the constructed test.

\section{Research Instruments}

Tools used in the study as follows:

1. Fact versus. Opinion (F vs. O) Test: Fact can be proven to be true or false and backed up by evidence. An opinion is a statement of what someone believes or thinks. F vs. O Test refers to the consideration used to distinguish which statement or evidence based on Fact and which one based on Opinion. Therefore, the practice of differentiation of Fact from Opinion can help persons to think analytically and to develop synthetic thinking for problem-solving, which ultimately may lead to right decision making. The test is covering 30 multiple-choice items in three categories:-Thai language \& Social Study (13 items), Science ( 9 items), and others (i.e., newspaper, social media and daily life events) (8items).

2. The Ordinary National Education Test (O-NET) is the assessment of academic proficiency for grade 6 , grade 9 , and grade 12 students. This test comprises of 8 major subject areas based on the national education curriculum: 1) Thai Language 2) Mathematics, 3) Science, 4) Social Science, Religion, and Culture, 5) Health and Physical Education, 6) Art, 7) Career and Technology, and 8) Foreign Languages. The O-NET based test consists of a catalogue of questions that mostly concerned the development of students' analytical thinking which were selected from O-NET and Pre O-NET from year 2005 to 2009. Also, the questions were prior reviewed and investigated by experts and specialists based on the criteria of analytical thinking ability. The test consists of 30 multiple-choice items in four categories: Thai language \& Social Study (14 items), Science (8 items) and Mathematics (8items).

\section{The Process of Analytical Thinking Skills (ATS) Test Development}

A chart depicting the process of the ATS test development illustrated all eight hierarchy steps as shown in the Figure1. The steps of the Test were as followed: 
1. Defining the objectives of the test development for $6^{\text {th }}$ grade students. In this step, the researchers evaluated the relative importance of the objectives and the content in each subject, including additional questions with respect to the learning objectives. This test aimed at tracking the progress in development of students' analytical thinking ability (Formative).

2. Studying theories and related researches. The researchers studied relevant domestic as well as international scientific documents for the development of the analytical thinking skills test that was based on the Basic Core Curriculum, BE 2551(2008). Bloom's principles of Analytical Thinking are composed of analysis of elements, analysis of relationships and analysis of organizational principles (Bloom \& Krathwohl, 1956).

3. Sixty question items were constructed based on Bloom's analytical thinking principles and the content of core curriculum BE 2551(2008) for $6^{\text {th }}$ grade. Then, a draft test was made and next step was the solutions. The questions were formed in the type of multiple choices with four options. Only one is the correct answer and the three other options are incorrect.

4. The researchers invited three experts to review and investigate the 60 questions and check the index of consistency (IOC) of the test. During this step, 40 items were selected by experts' scoring with IOC value.

5. The 40 questions were then piloted with $306^{\text {th }}$ grade students at one school in Bangkok. The examination time was 50 minutes.

6. The researcher analysed each item's difficulty level and discrimination index using Simple Items Analysis (SIA) 1.0.1(Piromsombat, 2002). Finally, 30 items were selected as being in range of $0.2-0.8$ of difficulty and yielding at least 0.2 for the value of the discrimination index. Program analysis determined which item should be stored, improved or cut off (see Table 1). A total of 30 items were screened and drafted for the test.

7. The 30 selected questions were then tested on sample students to assess the test difficulty index, discrimination index and reliability for the second time using the Test Analysis Program (TAP) 6.65 (Brooks \& Johanson, 2003).

8. Norm was constructed in form of the normalized T-score and adjusted T-normal by using size Least Squares Method. Then, the manual of the ATS test was written. This involved the measurement of the characteristics of knowledge and skills associated with the development of students learning focusing on analytical thinking skills in the Basic Education Curriculum 2008.

\section{Data collection and Analysis}

A total of $35676^{\text {th }}$ grade students took part in the examination in July 2014. Two ATS tests were employed, the F vs. O test and O-NET based test. Both tests comprised 30 items having four options. One was the correct answer and the other three were incorrect choices in both F vs. O and O-NET based test. The examination time was 45 minutes and the total scores were 30. Each correct response scored as 1 and each incorrect response scored as 0 . 


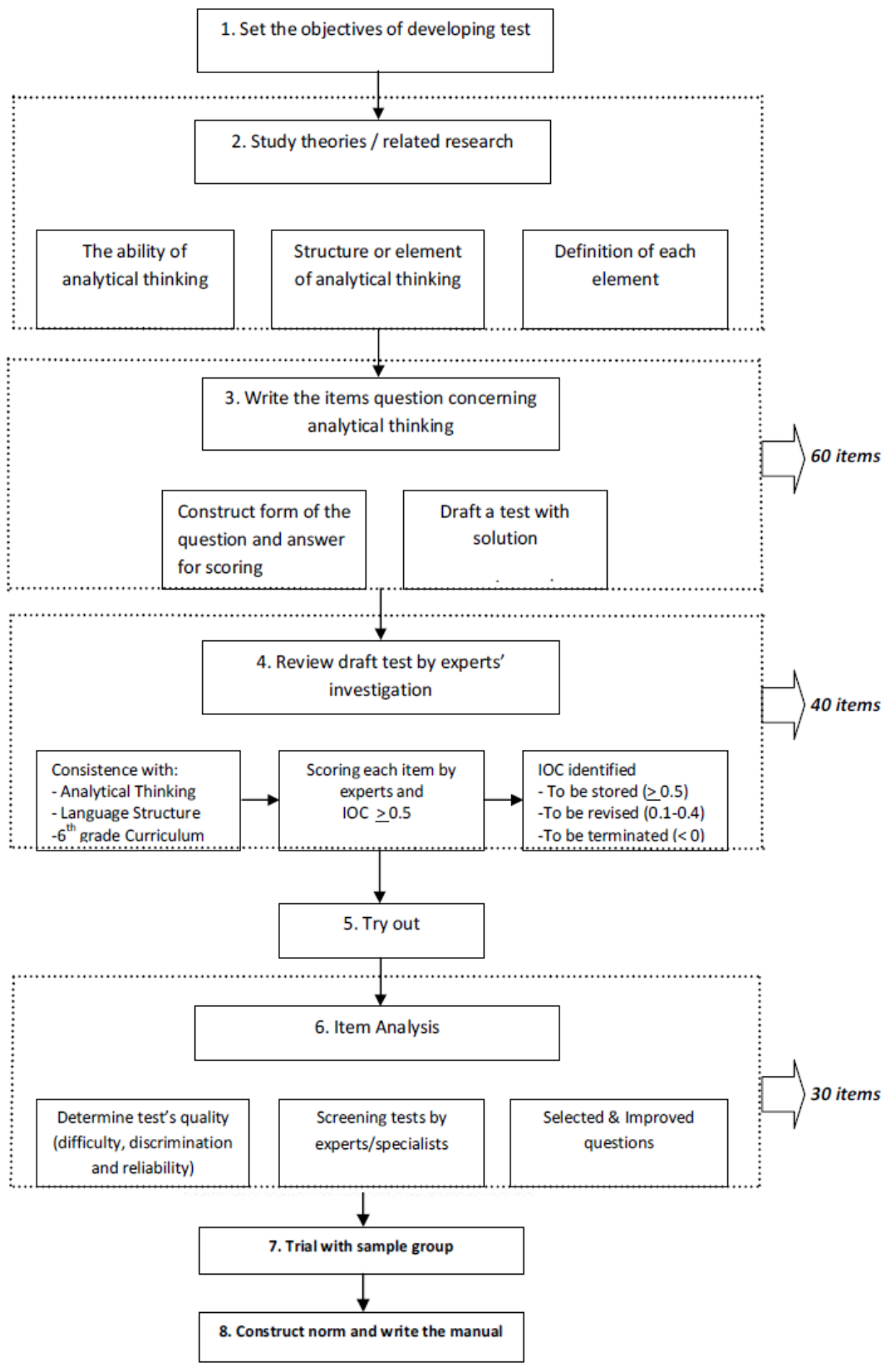

Figure 1: Chart shows analytical thinking test development process

International Journal of Instruction, July $2016 \bullet$ Vol.9, No.2 
The data obtained from all 3567 students were processed by TAP 6.65, SIA 1.0.1 and SPSS 22 statistical program and analysed. Scores were listed in descending order and the data were analysed in the following way. Descriptive statistics was used by the researchers such as mean ( $\overline{\mathbf{X}})$, percentage $(\%)$, and standard deviation (S.D.). Content validity was assessed by finding the value of Index of each item. The determination of Index of Objective Congruence (IOC) assured that each item is in congruence to analytical thinking at index value IOC $>0.50$ (sets the standard). The construct validity based on the correlation coefficient values between item scores and total-test scores (item - test correlation).Test reliability was assessed by Kuder-Richardson's KR-20 formula and normalization of the test was established by test result transformation to normalized T-score and the adjusted T-normal by using size Least Squares Method.

\section{FINDINGS}

\section{Constructing F vs. O Test}

The researchers based the test development on $6^{\text {th }}$ grade's Basic Core Curriculum 2008 and Bloom's principles of Analytical Thinking theory. The test was divided into 3 categories: Thai language \& Social study, Science and Others. The total number of questions was 60 as shown in Table 1. The question items of the ATS Test (F vs. O Test) were analysed with regard to the difficulty value and the discrimination power and selected From the result analysis of the constructed ATS Test ( $\mathrm{F}$ vs. O Test), the researcher selected only when measuring in range of $0.20-0.80$ and 0.20 or higher, respectively. Any item question yielding a discrimination power value below 0.2 was revised or cut off.

Table 1: Number of questions classified in each category

\begin{tabular}{lcc}
\hline & \multicolumn{2}{c}{ Number of Questions } \\
\cline { 2 - 3 } The ATS Test in each category & Created & Selected \\
\hline$F$ vs. O Test & $\mathbf{6 0}$ & $\mathbf{3 0}$ \\
Thai \& Social Study & 30 & 13 \\
Science & 15 & 9 \\
Others & 15 & 8 \\
\hline
\end{tabular}

\section{The Result Interpretation of $306^{\text {th }}$ Grade Students in Pilot Study}

Prior to the implementation of the ATS test, a pilot study was conducted with $306^{\text {th }}$ grade students in one school in Bangkok. The result interpretation is shown in Table 2.

Table 2: The result interpretation of $306^{\text {th }}$ grade students in pilot study

\begin{tabular}{cccc}
\hline Cut off points & Items $(N=40)$ & Interpretation & Action \\
\hline Difficulty Index $(P)$ & & & \\
\hline$\leq 0.20$ & 3 & Very Hard & Revise/Discard \\
\hline $0.21-0.40$ & 14 & Hard & Store \\
\hline $0.41-0.60$ & 18 & Medium & Store \\
\hline$\geq 0.61$ & 5 & Very Easy & Revise/Discard \\
\hline Discrimination Index $(D)$ & & & \\
\hline$<0.15$ & 6 & Poor & Revise/Discard \\
\hline $0.15-0.24$ & 6 & Good & Store \\
\hline$\geq 0.25$ & 28 & Very Good & Store
\end{tabular}




\section{Descriptive Statistics}

The analysis of descriptive statistics of F vs. O test and O-N ET based test was done by determining mean of scores $(\overline{\mathbf{x}})$ and standard deviation (S.D.) as shown in Table 3.

Table 3: Descriptive statistics values of Tests

\begin{tabular}{lccc}
\hline ATS Test & $N$ & Mean $(\overline{\mathbf{x}})$ & S.D. \\
\hline$F$ vs. O Test & 3567 & $12.4244(41.40 \%)$ & 4.85249 \\
\hline O-NET based Test & 3567 & $13.1693(43.86 \%)$ & 4.32596 \\
\hline
\end{tabular}

\section{Test reliabilities}

The test reliability was calculated using Kuder-Richardson's Internal Consistency (KR20) formula, measuring as 0.73 and 0.64 for the F vs. O test and O-NET based test respectively. Table 4 indicated that the $\mathrm{F}$ vs. $\mathrm{O}$ test was a reasonably reliable instrument in producing consistent scores in reference to Fraenkel \& Wallen (2008) claiming that the reliability value should be greater than 0.70 to suffice the confirmation of test reliability.

Table 4: The reliability of Fact vs. Opinion Test and O-NET based Test

\begin{tabular}{lcccccc}
\hline ATS Test & $n$ & $k$ & Total & S.E.M & $r$ & Result \\
& & & scores & (from KR20) & (KR20) & \\
\hline Fvs.O Test & 3567 & 30 & 30 & 2.519 & 0.731 & Reliability \\
O-NET based Test & 3567 & 30 & 30 & 2.570 & 0.647 & Unreliability \\
\hline
\end{tabular}

\section{Content Validity, Difficulty level (P) and Discrimination Power (D)}

Content Validity refers to the determination of the consistency index value between item questions and IOC value. The item questions were investigated and rated by at least three experts. Items were selected with an IOC value of at least 0.50 (Phongrat, 1997).The results of IOC value analysis showed item consistency ranging between 0.5 and 1.0. the item difficulty $(\mathrm{P})$ of $\mathrm{F}$ vs. $\mathrm{O}$ test, ranged between $0.21-0.61$ (Mean, 0.414). Discriminative power (D) values were in range of 0.08-0.57 (Mean, 0.374), which is in fulfillment of the requirements of the difficulty index value which was expected to range between 0.2 and 0.8 and discrimination was expected to be measured at least as 0.2 (Backhoff, Larrazolo \& Rosas, 2000). The analysis of the test quality left 30 items question for use potentially capable of the evaluation of students' analytical thinking skills.

For comparison of the total scores between F vs. O test and O-NET based test, the statistical t-test (Paired Sample correlations) was employed and determined the differences of significance at the 0.05 level. We found both tests were being correlated with measuring a correlation coefficient of 0.545 in the positive direction as shown in Table 5. Thus, this research presented consistent correlation between both tests in the moderate level. It was inferred that students who obtained the higher scores in the O-Net based test also achieved higher F vs. O test scores (Rovine M J. von Eye A, 1997). Hence, the ATS test was able to differentiate between students with higher and lower abilities. 
Table 5: Paired samples correlation

\begin{tabular}{lccc}
\hline ATS Test & $N$ & Correlation & Sig. \\
\hline Pair: $F$ vs. $O$ test \& ONET based test & 3567 & .545 & .000 \\
\hline
\end{tabular}

T-Test dependent for F vs. O test and O-NET based test is shown in Table 6, provided the difference value of mean, and standard deviations. For the $95 \%$ confidence interval of the difference and Sig. (2-Tailed) value illustrated two condition means which are statistically different, and often referred as the $\mathrm{p}$ value. The $\mathrm{t}$ value from calculation is equal to 10 , it is indicated that $\mathrm{F}$ vs. $\mathrm{O}$ test and O-NET based test had highly relationship and significant difference at .05level.

Table 6: t-test dependent illustrated the difference value of mean, and standard deviations

\begin{tabular}{|c|c|c|c|c|c|c|c|c|}
\hline & \multicolumn{6}{|c|}{ Paired Differences } & \multirow[b]{3}{*}{ df } & \multirow[b]{3}{*}{ Sig.(2-tailed) } \\
\hline & \multirow[b]{2}{*}{$\bar{x}$} & \multirow[b]{2}{*}{ S.D. } & \multirow[b]{2}{*}{ S.E.M. } & \multicolumn{3}{|c|}{$\begin{array}{l}95 \% \text { confidence interval } \\
\text { of the difference }\end{array}$} & & \\
\hline & & & & Lower & Upper & $\mathrm{t}$ & & \\
\hline Pair1 VAR0001-VAR0002 & -.744 & 4.404 & .073 & -.889 & -.600 & -10.10 & 3566 & .000 \\
\hline
\end{tabular}

The construct validity based on correlation coefficient value between item scores and total-test scores (Item-Test Correlation) was between 0.119-0.600, which was significantly related at 0.05 level. The correlation coefficients between scores in areas of Thai language \& Social Study, Science, Others and total-test scores ranged between $0.224-0.683,0.443-0.624$ and $0.469-0.604$ respectively, and were significant at 0.05 level as shown in Table 7. Additionally, the result showed that item 2,8,26 and 29 should be cut off because the correlation coefficient values (item/test) were larger than test reliability (KR20) value measuring 0.731 (Saiyos, L. \& Saiyos, A., 1995).

Table 7: Correlation coefficient values between item scores and total-test scores (Item-Test Correlation)

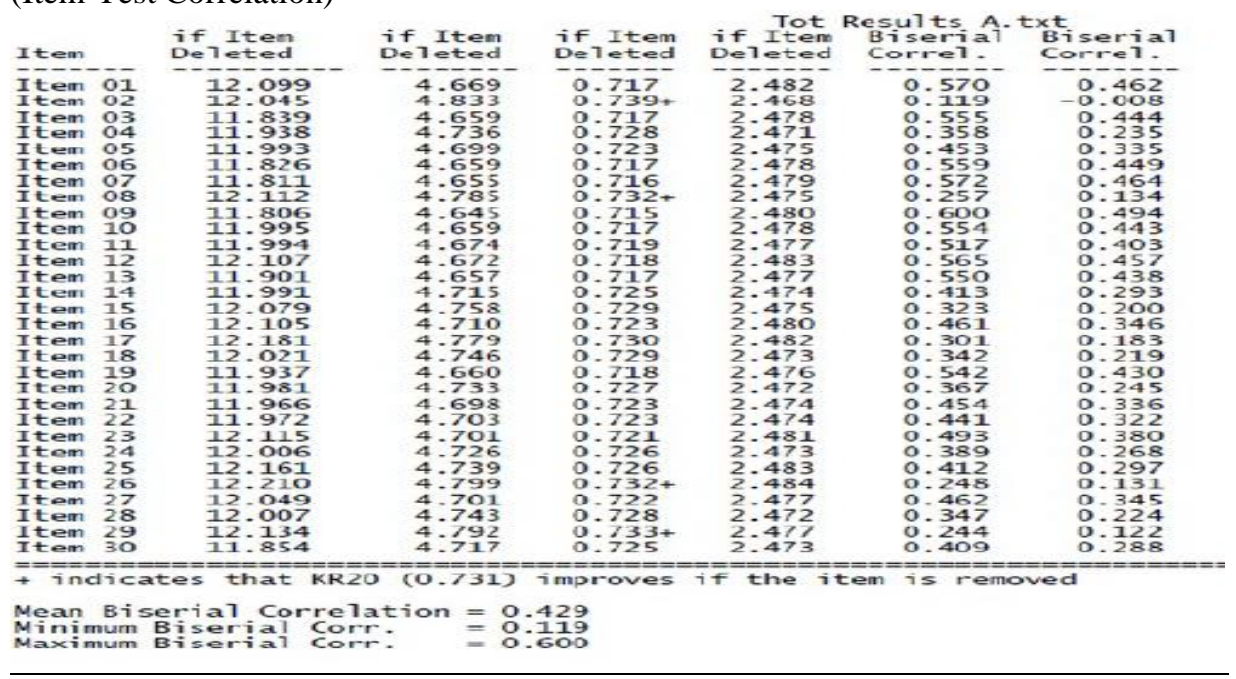


In addition, the normalization of the $\mathrm{F}$ vs. $\mathrm{O}$ test showed raw scores that range from 1 to 30, percentile rank from 0 to 100 and normalized $\mathrm{T}$ scores from T15.5 to T86.3 as illustrated in figure 2. For the interpretation of the $6^{\text {th }}$ grade student's ATS, an interference score was generated using the number of items completed with higher scores reflecting a better performance as follows; T-Scores of 35 or less was considered as "To be improved", T35-T45 was considered as "Low", T45-T55 was considered as "Moderate", T55-T65 was considered as "High", T65 or above was considered as "Excellent"(Taweerat, 1987).

The evaluation of students' analytical thinking skill in Samuthsakorn province using the $\mathrm{F}$ vs. $\mathrm{O}$ test revealed that $3.94 \%$ of students performed at the "Excellent" level, $6.57 \%$ ranked at the "High" level, 39.47\% at the "Moderate" level, $40.70 \%$ at the "Low" level, and $5.26 \%$ ranked at the "To be improved" level.

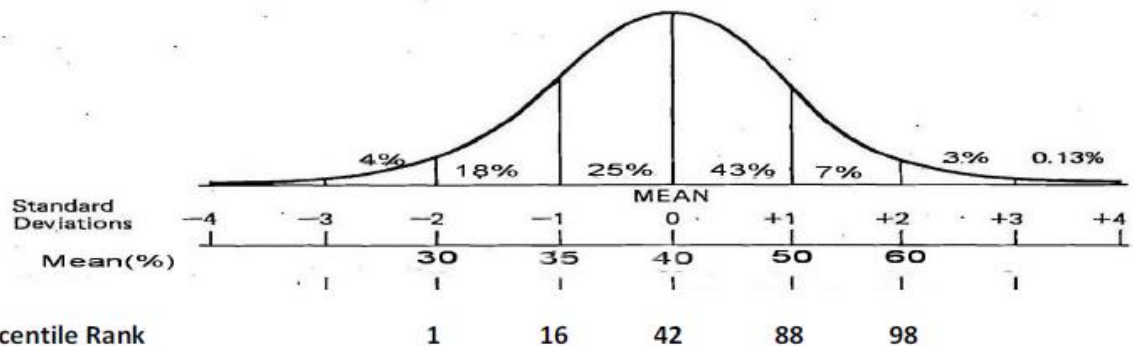

Figure 2: Norms of students' analytical thinking skills

Additionally, the results of F vs. O test revealed that the number of students who answered items correctly in Thai language \& social study, science and others as shown in Table 8.

Table 8: Number of students answered items correctly in each Category

\begin{tabular}{lc}
\hline \multicolumn{1}{c}{ Category } & Number of students \\
\hline Thai language \& Social Study & $38.14 \%$ \\
\hline Science & $32.61 \%$ \\
\hline Others & $29.25 \%$ \\
\hline
\end{tabular}

\section{DISCUSSION}

Teaching and learning pedagogy in Thailand's classrooms are focused on "lecturing" for being teacher-centred. It is claimed in this work that such an educational methodology may explain a lack of analytical thinking and also problem-solving skills in most Thai students. For this reason, the researcher was interested in developing an analytical thinking skill test in order to promote students' analytical thinking skills and likewise to evaluate their performance. The analytical thinking test used in this study was used to enhance the educational quality in Thailand with regard to the learning of analytical thinking and problem-solving skills. 
Analytical Thinking Skills practice is a thinking process and being an important factor in the development of children's intelligence to grow into adults who have quality for being critical to develop country (Triamchoedtiwong, 2006). Thinking skills and the knowledge application for solving problem and making decision are the important parts in the learning process in schools. Especially, students at grade 4-6 has focused on the development of cognitive skills following the core curriculum basic education 2008 with indicator of learning standard in using reason for decision and problem-solving in various situations appropriately. This is related with the study of logic and analytical thinking skills for $6^{\text {th }}$ grade students to provide the learners with enthusiasm and make them capable of discriminating which statement is fact or opinion.

This research aimed to develop a tool in form of a Fact versus Opinion test to measure the students' analytical thinking skills and to evaluate the test quality by assessment instrument. Students' variable in thinking skills had a considerable statistical effect on the test interpretation. Therefore, students' performance in analytical thinking ability was revealed to rank at the lower level. It was suspected that students' misunderstanding the question or items were too hard. With regard to the analysis results, the test reliability was 0.73 therefore it showed good qualities but the small amount of participants may have been related to the result again in the research. The statistical analysis provided information about the individual students' performance and aptitude to think analytically as well. We found that F vs. O and O-NET based test correlated consistently at .545. This indicates that the F vs. O test can be used as a tool for evaluation of $6^{\text {th }}$ grade students' analytical thinking skills and also, it can be used as a guideline for teachers to design other analytical thinking tests.

Furthermore, construct validity based on correlation coefficient between item scores and total-test scores showed the reasonable values. Therefore, the test is considered as the quality of being trustworthy.

\section{CONCLUSION}

With the development of an ATS test in form of F vs. O test in which the students' test scores in Samuthsakorn province was lower than expected, the obtained results showed that $40.7 \%$ of students had relatively low levels of analytical thinking skills. This might be correlated to the fact that the standard of education in this province was ranking in the "low" group. Additionally, one factor which may ascribe to such result is the educational situation of up-country schools in Thailand for presenting lower educational standards as in Bangkok city.

From this study, ATS test will be beneficial for students in developing their analytical thinking, problem solving ability and right decision-making. And also, the test is able to reflect the students' analytical thinking skills and to develop them into the higher-order thinking i.e., synthetic, creative and critical thinking, which meets the Core Curriculum 2008 objectives and the IV educational standard that prescribes the learners' ability. Moreover, learning and teaching processes should be focused on the content of fundamental tests in order to develop the students' analytical thinking skills into higher level. The question items were performed in compliance with standard methodology and 
rated as in medium level of difficulty. The discrimination power was in the acceptable criterion. Nevertheless, the above results indicated that the test should have to be improved more for higher validity and reliability.

The suggestion for teachers in using the analytical thinking test as a supplementary tool for developing the students' thinking ability is that they should place more emphasis on the learning activities concerning the analytical thinking. For example, design the activities or exercises that were relevant to the analytical thinking and apply them within context, gender and age of students.

\section{ACKNOWLEDGEMENTS}

This research could not have successfully completed without the kindness and help of our colleges Dr. Darapond Triampo and Dr. Charin Modchang, Also thanks to Dr. Stefan Schreier, language editor for editing our manuscript draft. And special thanks also to Director of Schools under the Primary Education Office of Samuthsakorn Province, for their help in providing facilities in data collection. Primarily, I am grateful to the lecturers of the Institute for Innovative Learning at Mahidol University for their help during my fieldwork.

\section{REFERENCES}

Art-in, S. (2012). Development of Teachers' Learning Management Emphasizing on Analytical Thinking in Thailand. Procedia Social and Behavioral Sciences Journal, 46, 2012, 3339-3344 http://dx.doi.org/10.1016/j.sbspro.2012.06.063

Backhoff, E., Larrazolo, N. \& Rosas, M. (2000). The Level of Difficulty and Discrimination Power of The Basic Knowledge and Skills. Electrónica deInvestigaciÓn Educativa, 2(1). Retrieved on April 1, 2007. From http://redie.uabc.mx/vol2no1/contentsbackhoff.html

Bloom. B S. \& Krathwohl, D. R. (1956). Taxonomy of Educational Objectives: The Classification of Educational Goals, by a committee of college and university examiners. Handbook I: Cognitive Domain. New York, Longmans, Green.

Brooks, G. P., \& Johanson, G. A. (2003). Test Analysis Program. Applied Psychological Measurement, 27, 305-306.

Charoenwongsak, K. (2002). Critical Thinking. Bangkok: Successmedia Ltd.

Charoenwongsak, K. (2003). Critical Thinking. Bangkok: Successmedia Ltd.

Chaijaroen, Sumalee, and others. (2006). Development of Learning Innovations That Enhancing Thinking Potential. Faculty of Education, Khonkaen University.

Fraenkel, J.R. \& Wallen, N.E. (2008). How to Design and Evaluate Research in Education (7th ed.).New York: McGraw-Hill.

Kaewsudjarit, J. (1998: 95-97). A Development of a Feature of Thinking Scale for Phathom Suksa Four to Six Students, unpublished master's thesis, Bangkok, Chalalongkorn University. 
Ministry of Education. (2001). Basic Education Curriculum B.E. 2544 (A.D.2001).Bangkok: Kurusapa Ladprao Publishing.

Ministry of Education. (2006). A Report of Synthetic Approach and Technique in Instructional for Enhancing the Analytical Thinking Skill. Bangkok: The Agricultural Cooperative Association of Thailand.

Ministry of Education. (2008). The Core Curriculum for Basic Education of 2008. Bangkok: The Printing Shop of Thailand National Agricultural Cooperative Group.

Navapornpaisarn, P. (1992). The Investigation of The Watson-Glaser Critical Thinking Appraisal for Mayhayomsuksa Students, unpublished master's thesis, Chulalongkorn University, Bangkok (Thailand).

Pimsai, S. (2002). A Development of a Critical Thinking Test for Prathom Suksa5 and Prathom Suksa 6 Students. unpublished master's thesis, Ubon Ratchathani Rajabhat University, Bangkok (Thailand).

Piromsombat, C. (2002). Simple Item Analysis SIA. Faculty of Education, Chulalongkorn University, Bangkok, Thailand. [in Thai].

Phongrat, T. (1997). Social Research Methods, Bangkok: Charempol printing.

Rovine M J. von Eye A. (1997). A 14th Way to Look at a Correlation Coefficient: Correlation as the Proportion of Matches. The American Statistician, Vol. 51, No. 1 (Feb., 1997), 42-46. Stable URL: http://www.jstor.org/stable/2684692

Saiyos, L. \& Saiyos, A. (1995). Educational Research Techniques 5th Edition. Bangkok: Suviriyasarn. [in Thai].

Sinlarat, P. (2000). Public and Private Sectors in Thai Higher Education. In P. Sinlarat (Ed.). Higher Education in Thailand: Critical perspectives. Bangkok: Textbook and Academic Document Center, Faculty of Education, Chulalongkorn University.

Susaorat, P. (2012).The Development of Science Instructional Model Emphasizing Contextual Approach to Enhance Analytical Thinking and Application of Knowledge for Lower Secondary School Students, Ph.D. thesis (research and curriculum development), Bangkok: Graduate school. Srinakharinwirot University. Photocopying. [in Thai].

Stella, C. (2003). The Study Skills Handbook $2^{\text {nd }}$ Edn. Palgrave-Macmillan: Basingstoke.

Taweerat, P. (1987). The Construction and Development of Achievement Test. Bangkok: The Office of Educational and Psychological Test. Srinakharinwirot University. [in Thai].

The Office for National Education Standards and Quality Assessment [Public Organization] (ONESQA). (2007). Conclusion of Synthetic Findings in School External Audit, Basic Education Level (The First Round 2001-2005). Searching on 19 January 2007, from http://www.onesqa.or.th/th/home/index.php. 
Triamchoedtiwong, U. (2006). The Effects of Analytical Thinking on Classifying Ability of Prathom Suksa III Students at Bangkok Christian College in Bangrak District, Bangkok. Master's Project, M.Ed. (Educational Psychology). Bangkok: Graduate School, Srinakharinwirot University.

Wheeler, P. and Haertel, G. (1993). Resource Handbook on Performance Assessment and Measurement. Berkeley, CA:The Owl Press.

Wirach-chai, N., Wongwanich, S. \& Ruengtrakoon, A. (2004). Evaluation of Educational Reform Based on National Education Act1999. Bangkok, Thailand. The Secretariat of Educational Council, Ministry of Education.

\section{Turkish Abstract}

Gerçeğe karşı Düşünce Farkına Dayalı Olarak Öğrencilerin Analitik Düşünmelerini Değerlendiren Bir Test Geliştirmek

Bugünlerde, Tayland'da eğitimin en büyük zorluklarından biri öğrencilerin düşünme becerilerini artırmak ve geliştirmek. Bu araştırmanın asıl amacı 6. sınıf öğrencileri için analitik düşünme testleri geliştirmek ve öğrencilerin analitik düşüncelerini değerlendirmektir. Örneklem 35676. sınıf öğrencisinden 2014 akademik yılında Samuthsakorn bölgesinde, Tayland'da bu zamana kadar analitik düşünme testi için ulaşılan en büyük örneklemdir. Veri toplama araçları analitik düşünme becerileri testi; Gerçek vs Düşünce testi (G vs. D testi) ve Olağan Ulusal Eğitim temelli test (O-NET). Toplanan veriler TAP 6.65, SIA1.0.1 ve SPSS 22 istatistik programlariyla analiz edilmiştir. Sonuçlar G vs. D testiyle O-NET temelli testler arasında tutarlık tespit etmiştir. Ayrıca, birçok 6. sınıf analitik düşünme becerilerinde yetersiz düzeydedirler. İhtiyaç duyulan gelişmeler aracılığıyla geliştirilen $G$. ve $D$. testinin öğrencilerin analitik düşünme becerilerinin değerlendirilmesi ve yükseltilmesi için önemli olduğunu düşünmekteyiz.

Anahtar Kelimler: analitik düşünme becerisi, gerçek vs düşünce, O-NET temelli test, test kalitesi, ATS test

\section{French Abstract}

Développement d'un Test pour Évaluer la Pensée Analytique d'Étudiants Basée sur Fait contre Différenciation d'Avis

De nos jours, un des plus grands défis d'enseignement en Thaïlande est le développement et la promotion des compétences de pensée des étudiants. Les buts principaux de cette recherche étaient de développer le test pensant analytique sur des étudiants de 6ème et évaluer la pensée analytique des étudiants. L'échantillon a été composé de 3567 étudiants de 6ème d'année d'universitaire de 2014 d'écoles dans le domaine Samuthsakorn, la plus grande taille type atteinte jusqu'ici pour un test pensant analytique en Thaïlande. Les instruments pour rassembler des données étaient le test de compétence pensant analytique; fait contre. Test d'avis (F contre. O le test) et le test basé Éducatif national Ordinaire (l'O-réseau le test basé) .Collected des données a été analysé par DÉCOUVRENT 6.65, SIA1.0.1 et SPSS 22 programmes statistiques. Les résultats ont révélé la cohérence(consistance) statistique entre $\mathrm{F}$ contre. O testent et l'O-réseau le test basé. De plus, la plupart des étudiants de 6ème étaient dans le niveau "Insatisfaisant" de compétences 
pensantes analytiques. Quoique les améliorations soient très nécessaires, nous croyons que notre Fait développé contre le test d'Avis convient à la promotion et l'évaluation des compétences pensantes analytiques des étudiants.

Mots Clés: habileté (compétence) pensante analytique, fait contre avis, O-réseau test basé, qualité de test, ATS test

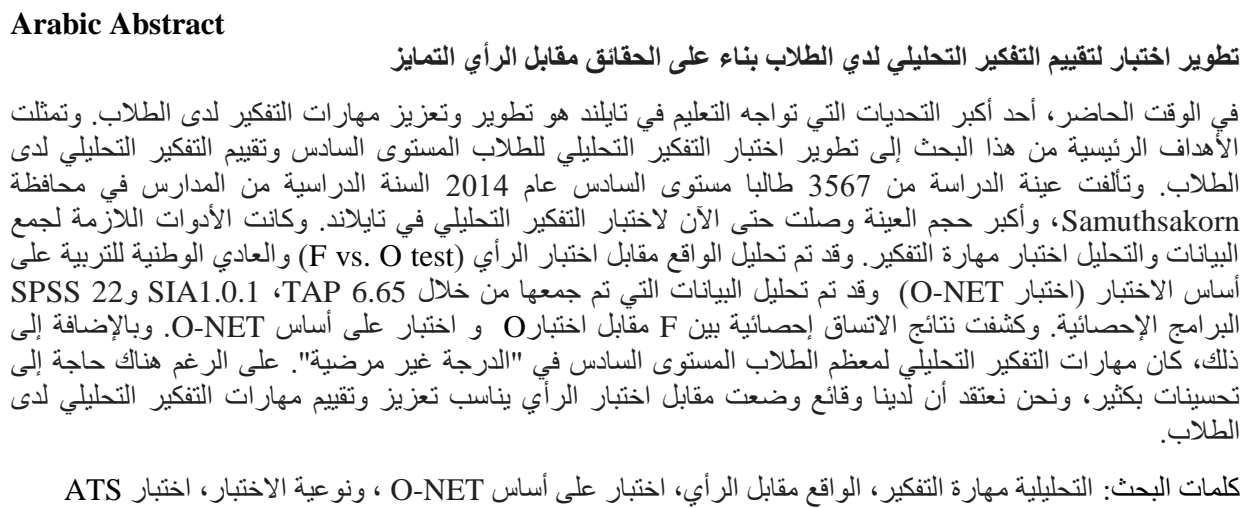

\section{German Abstract}

Entwicklung eines Test-analytisches Denken von Studenten auf Fact gegen Differenzierung Basierend auf auswerten Stellungnahme

Heutzutage ist eine der größten Herausforderungen der Bildung in Thailand ist die Entwicklung und Förderung der Denkfähigkeiten der Schüler. Die Hauptziele dieser Forschung waren die analytische Denken Test für 6. Klasse Schüler zu entwickeln und die Schüler analytisches Denken zu bewerten Die Probe von 3567 6. Klasse Studenten 2014 Studienjahr der Schulen in der Provinz Samut Sakhon zusammengesetzt war, die größte Probengröße bisher für ein analytisches Denken Test in Thailand erreicht. Die Instrumente für die Datensammlung waren die analytische Denken praktische Prüfung; Tatsache vs. Meinungstest (F vs. O-Test) und gewöhnlichen nationalen Bildungs basierten Test (O-NET basierte Test). Die gesammelten Daten wurden durch TAP analysiert 6,65, SIA1.0.1 und SPSS statistischen Programmen. Die Ergebnisse zeigten, statistische Konsistenz zwischen F vs. O-Test und O-NET-basierter Test. Darüber hinaus waren die meisten der 6. Klasse Schüler in "Unbefriedigend" Ebene des analytischen Denkens Fähigkeiten. Obwohl Verbesserungen dringend benötigt werden, glauben wir, dass unsere entwickelte Tatsache vs. Meinungstest passt Förderung und Bewertung der analytischen Denkfähigkeiten der Schüler

Schlüsselwörter: analytisches denken fähigkeit, tatsächlich gegen meinung, O-NET-basierter test, der qualität der test, ATS test 


\section{Malaysian Abstract \\ Pembangunan Ujian untuk Menilai Analisis Pelajar Berfikir Berdasarkan Fakta berbanding Pendapat Pembezaan}

Pada masa kini, salah satu cabaran terbesar pendidikan di Thailand ialah pembangunan dan promosi kemahiran berfikir pelajar. Tujuan utama kajian ini adalah untuk membangunkan ujian pemikiran analitikal untuk pelajar gred 6 dan menilai pemikiran analitikal pelajar. Sampel terdiri daripada 3567 pelajar 6 gred 2014 tahun akademik sekolah di wilayah Samuthsakorn, saiz sampel yang terbesar dicapai setakat ini untuk ujian pemikiran analitikal di Thailand. Instrumen yang digunakan untuk mengumpul data adalah ujian kemahiran berfikir analisis; Fakta vs ujian Pendapat (F vs ujian O) dan Biasa ujian berasaskan Negara Pendidikan (berdasarkan test O-NET) data. Collected dianalisis melalui TAP 6.65, program statistik SIA1.0.1 dan SPSS 22. Keputusan mendedahkan konsisten statistik antara $\mathrm{F}$ vs ujian $\mathrm{O}$ dan ujian berasaskan O-NET. Di samping itu, kebanyakan pelajar gred 6 berada pada tahap "tidak memuaskan" kemahiran pemikiran analitikal. Walaupun penambahbaikan amat diperlukan, kami percaya bahawa kami Fakta dibangunkan vs ujian Pendapat sesuai dengan kenaikan tahap dan penilaian kemahiran pemikiran analitikal pelajar.

Kata Kunci: kemahiran berfikir analitikal, fakta vs. pendapat, ujian berasaskan O-NET, kualiti ujian, ujian ATS 